\title{
More than Tools: ICTS Facilitating Alternative Opportunity Structures for Social Movements
}

\author{
Fatima K. Espinoza Vasouez
}

\begin{abstract}
Though ICTs are critical for social movements, political orders, and the machinery of the modern state, research has not addressed how they are important, the purpose of this exploratory study is to attend take the first step towards theorizing the role of ICTs in social movements. The study is guided by the following research question: How does the resistance movement relate to the opportunity structures? A mixed-method case study of the Honduran Resistance Movement was conducted. Members of the movement, civil society organizations, the government and international organizations were interviewed and observation of mobilizations and meetings were conducted, as well as collection of qualitative data from newspapers and social media. We found that social movements engage in a bricolage behavior to make the most out of their available ICTs and mobilizing structures and create opportunities to participate in political processes.
\end{abstract}

KeYwords: Infrastructures, ICT, beyond GDP, human development index 


\section{Introduction: how icts are important for social movements}

Given the variety of fields that study social movements and the diverse shapes social movements take, it has been difficult to answer questions about how ICTs are important to social movements (Garrett, 2006; D. Hess, Breyman, Campbell, \&t Martin, 2008; D. Hess, 2005). Even though there is an ongoing conversation about ICT adoption and reconfiguration by social movements, (Klein, 2012; Le Dantec, 2012; Moghadam, 2012; Singerman, 2004) research has not fully addressed the issue of how ICTs are important to social movements (Garret, 2006, (V. Carty, 2011; V. Carty, 2010). Moreover, research has been done on the goal of social movements (S. M. Buechler, 1995; Pichardo, 1997, Melucci, Keane, \& Mier, 1989), their motivations (Boggs, 1983; Marx, Engels, \& Smelser, 1973), their interactions (Granovetter, 1983; Lichbach, 1995; Park, 1939; Park \& Turner, 1967); individual rationalization processes (Chong, 2000; Lichbach, 1996; Olson, 1971), their success or failure (D. Mcadam, 1983; D. Mcadam, 1989; S. G. Tarrow, Tarrow, \& Cornell University, 1989; C. Tilly, 1978), their conditions for the development (Smelser, 1963); the way collective action happens (S. M. Buechler, 2000; McCarthy \& Zald, 1977; D. A. Snow, Zurcher, \&t Eklandolson, 1980) and how participants interpret issues (Benford \& Snow, 2000); yet the role of ICTs in those processes has not be theorized.

It is increasingly important to develop an overarching theory to address ICTs in social movements, as ICTs give social movements the potential to "reach a new level in the way they mobilize, build coalitions, inform, lobby, communicate and campaign" (Donk, 2004) (p. 1). The goal of this exploratory study is to start addressing this gap by taking a first step towards developing an overarching theoretical framework to the systematic study of ICTs in social movements (Ameripour, Nicholson, \& Newman, 2010; Donk, 2004; Eltantawy Et Wiest, 2011; S. G. Tarrow, 2011). The research question that guides this study is: How does the resistance movement relate to the opportunity structures?

\section{Theoretical framework: the contentious politics model}

Social Movements are contentious challenges to authorities (Melucci et al., 1989; C. Tilly, 2002), with symbolic construction and maintenance of collective identity (Melucci, 1989) and the ensemble of interconnected social movement organizations striving for similar goals (Donk, 2004; McCarthy \& Zald, 1977). McAdam, McCarthy and Zald (1996) proposed an integrated model that provides a framework that is the result of an emerging consensus among social movement researchers (Della Porta, Kriesi, \& Rucht, 1999), and allows studying the integration and interaction of social movements' organizations, symbolic constructions, and their institutional environment.

The first component of the model is Opportunity Structures, which consist of the institutional political environment and the structures and constraints it provides for 
political expression and participation. These are the set of structure that transgressive politics confront (della Porta, et al., 1999; Kriessi, 2004; McAdam, 2001; Tarrow, 2011). Opportunity structures can be: governmental policies, institutions, legislation, the media, changes in the economy, historical precedents, and changes in public policy (Meyer, 2004). Using a state-centered approach to opportunity structures (Tarrwo, 1996) it is possible to examine government centralization, strength of civil society, and influence of the private sector; to explain the emergence, shape and outcomes of social movements (Tarrow, 2011). Conversely, opportunity structures can be influences or reconstructed to be more welcoming to cultural pluralism and contentious politics (H. Kriesi, 1995b).

Mobilization around an issue is more likely to happen if there is an existing Mobilizing Structure; they are organizational infrastructures, or associational networks in the onset of contention (Garrett, 2006; D. McAdam, Tarrow, \& Tilly, 2001), which enable individuals and groups to organize and engage in collective action (J. D. McCarthy, 1996). Mobilizing Structures can be formal organizations, such as NGOs, civil society organizations, or labor unions (Davis \& Zald, 2005; McCarthy \&t Zald, 1977); or informal organizations such as activists' networks, churches or friendships (H. Kriesi, 1989; H. Kriesi, 1995a). As this model assumes a dynamic relation between the three factors, it is helpful in providing a holistic explanation of the role of ICTs in social movements' emergence, mobilization and development. This study explores the use of ICTs by social movements to create new mobilizing and opportunity structures.

\section{Context: the case of the honduran resistance movement}

Since democracy was reinstated in 1982 there have been seven consecutive democratically elected presidents, until 2009 when president Manuel Zelaya was deposed. This case is relevant because it was the first one in a wave of revolts around the world in the last four years, which relied in ICTs to organize and get the world's attention. It precedes other well-known movements like the ones in Egypt, the United States, Chile, Iran and Tunis. It shares similarities with them, like the use of social media, the attention they received from the international community and media, the reconfiguration of technologies, and its composition of geographically dispersed and heterogeneous organizations and communities (Alinsky, 1941; Warren, 2001). These similarities allow me to apply the theoretical framework across those cases in the future. Moreover, yhis case will address the lack of studies of ICTs and Social Movements in Latin America

\section{METHOD}

Considering social movements are too complex and multifaceted to be adequately grasped by any single method, multiple strategies of data elicitation were used in order to address such intricacies (Babbie, 2008; Burawoy, 1991; Burawoy, 1998; Feagin et al., 1991; Feagin 
et al., 1991; Lichterman, 2002; D. A. Snow \& Trom, 2002). Qualitative data analysis was conducted from sixteen semi-structured interviews, websites, Facebook, Twitter, blogs, newspapers, and official documents. Participants were members of the resistance, government employees, members of international and local NGOs and members of independent media. Sampling was done using the snowball technique, this allowed obtaining a wider range of participants, reduced possibility of coercion, reduced the possibility of researcher bias, and facilitated participants' trust . In order to analyze the movement from its emergence to its stabilization, the timeframe of the phenomenon is June 2009, when the coup happened, to November 2012 in which elections took place and the resistance's political party participated in primary elections.

\section{FINDINGS}

\section{A Snapshot Opportunity Structures in Honduras Before the Coup}

Honduras has eight political parties, however the country has been locked into a twoparty patronage system by the National Party and the Liberal Party; neither of which has ever focused heavily on ideology or a consistent political program. Both parties are considered center-right in political orientation (Ruhl, 2010).

Honduras developed strong democratic norms, healthy voting behavior, and a strong civil society. Formal group activism with strong political referent like human rights organizations, women's rights, LGBT, peasant, teachers and worker's unions, cooperatives, and professional groups, has been found to have the highest impact on the state. On the other side, communal- level civil society, like neighborhood organizations, though it had the strongest tendency to communicate with the government, it has no been found to contribute to system-level democracy (Booth \& Richard, 1998).

Hondurans were deeply dissatisfied with governmental institutions and economic performance, they were disgusted with civilian politicians in both traditional parties, to the point that 55\% of Hondurans refused to identify themselves by party (Ruhl, 2010). President Zelaya's attempted to address this discontent by implementing measures that made the private sector very unhappy. They included the country's accession to ALBA (Alternativa Bolivariana de las Americas) the integration alliance initiated by Venezuelan president Hugo Chavez, a sixty percent increase in the minimum wage, financial support for alternative media, and a national opinion poll on whether there should be a referendum on convening a legislative assembly which would take place during the elections on November 29, 2009 (Peetz, 2009). Even though the military had been reduced by presidents Carlos Roberto Reina and Carlos Flores by more than half, and their powers and privileges including control over the police and the national telecommunication systems were taken away, they were still one of the most respected institutions by the private sector (Ruhl, 2010). 


\begin{tabular}{|l|l|l|l|}
\hline Media & $\mathbf{2 0 0 9}$ & $\mathbf{2 0 1 0}$ & $\mathbf{2 0 1 1}$ \\
\hline Population & $7,869,089$ & $8,041,654$ & $8,200,795$ \\
\hline Number of Homes & $1,690,775$ & $1,737,262$ & $1,737,496$ \\
\hline Television & $1,180,546$ & $1,260,215$ & $1,259,375$ \\
\hline $\begin{array}{l}\text { Number of Homes with a } \\
\text { radio }\end{array}$ & $1,368,852$ & $1,371,973$ & N/A \\
\hline $\begin{array}{l}\text { Number of homes with a } \\
\text { computer }\end{array}$ & 204,400 & 246,573 & N/A \\
\hline $\begin{array}{l}\text { Number of homes with a } \\
\text { cell-phone }\end{array}$ & $1,345,310$ & $1,398,332$ & $1,478,462$ \\
\hline Cell phone Density & $96 \%$ & $118 \%$ & $96 \%$ \\
\hline Internet Users & 737,610 & 892,050 & N/S \\
\hline $\begin{array}{l}\text { Internet Users Number of } \\
\text { users per 100 habitants }\end{array}$ & 9.20 & 11.09 & N/A \\
\hline $\begin{array}{l}\text { Table 1. Honduran ICT Indicators 2009-2011 (Source: CONATEL National } \\
\text { Corporation of Telecommunications) }\end{array}$ \\
\hline
\end{tabular}

By June 2009 Hondurans had the most access to ICTs than ever, while only $12 \%$ of homes had a computer, and $9 \%$ of its population were Internet users, the number of cybercafes and community information centers had grown consistently in the last few years. Right before the coup there were 349 radio stations, 71 television stations, and over 7.5 million cell phones. The most popular media outlets were owned by the Televicentro Corporation, which also owns the larges cable companies, newspapers, cell-phone companies and Internet service providers. The rest were owned by smaller private companies, independent journalists, and worker unions throughout the country. The deep political polarization the country was facing was reflected and arguably fueled by the media. Corporate ICTs, much like the private sector, aligned with the military (Ruhl, 2010) and against Zelaya; they argued his measures would turn Honduras into a communist country. Moreover, Televicentro journalists would interview military members on a daily basis and asked them for "advice" on how to solve the "crisis caused by Zelaya".

"Media members would ask the chief of the Armed Forces, Romeo Vasquez to "solve" the situation. They would ask them: "What are you going to do? I think in a way they were asking him to perpetrate a coup." (International 1)

On the other side, independent ICTs, though not clearly aligned with Zelaya at first, did show his initiatives on a more favorable light.

"Mel counted on the support of small media, like Cholusat, Canal 6 and Radio Progreso, that focused more on development and who supported popular causes. They liked Mel's discourse about 'giving to the people'" (International 1) 
Hence, there was an environment of deep polarization among political and governmental institutions, where civil society was strong and well organized, where the private sector aligned with the military against the president and there was an consistently increasing number of people accessing ICTs.

\section{Emergence of the Resistance Movement}

Shortly after his inauguration in 2006, Zelaya (from the Liberal Party) grew widely unpopular amongst the conservative sector. Zelaya's opposition feared he intended to remain in power, so the day of the poll the military seized him and expelled him to Costa Rica. The National Congress met in an emergency session, declared Zelaya was no longer president, and swore in the president of congress Roberto Micheletti (also from the Liberal Party) as the new president of the republic. Micheletti then replaced all members of the cabinet who did not accept Zelaya's expulsion. While the OAS, the UN General Assembly and the rest of the international community unanimously declared the events of June 28 constituted a coup d'état against a democratically elected government, in Honduras the conservative sector and Micheletti supporters celebrated the expulsion of Zelaya. The days following the coup tens of thousands of citizens who either approved of Zelaya's measures or repudiated the coup went to the streets to protest. Coup protesters, independent media and civil society organizations formed the National Front of Popular Resistance (The Resistance).

\section{The Movement as Bricolateour}

Current ICTs give social movements the potential to "reach a new level in the way they mobilize, build coalitions, inform, lobby, communicate and campaign" (van de Donk et al; 2004 p. 1); they are "changing the way social movements mobilize, realize new political opportunities, and shape the language in which movements are discussed" (Garret, 2006 p. 15). This is possible not only by the technology affordances, but by the way they are used by movements; in the case of the Honduran Resitance Movement. Bricolage is the creation of objects with materials at hand, re-using existing artifacts and incorporating bits and pieces (Levi-Strauss, 1966). Is a modality of thinking and a behavior, which is common in developing countries or places where there is hardship or less stable political environments (Silva, 2002). The improvisations that result from bricolage are not uninformed or awkward decisions, but the enactment of quick and unexpected solutions in a sudden crisis (Ciborra, 1992), a rational and adaptive behavior in uncertain or volatile environments (Njenga \& Brown, 2012). Bricolage involves review and collection of the materials at hand, determination of use, and rearrangement including new uses of the existing material as response to the environment (Hatton, 1989). The resistance had to make do with the technology they had at hand (Levi-Straiss, 1947: 17), no only because it 
was a new organization that did not have a lot of resources, but because in many instances they found themselves in precarious situations (Hatton, 1989). The most salient ways the movement did bricolages with ICTs were to create alternative Opportunity Structures (to participate in political processes) fight repression and to mobilize.

\section{Social Ferment: Looking For Alternatives}

Members of the resistance concur on the circumstances that reinforced their desire to protest. Participants narrated how that morning they all woke up to the news that the president has been expelled out of the country. They talk about how during the first few hours after they had found out that there had been a coup, they did not have access to reliable information through corporate media, as corporate TV and Radio stations broadcasted movies or music in lieu of their regular programs, or provided biased version of the events.

"I woke up at 4 am that morning, I turned on the TV to Channel 8 the official government channel. All of a sudden, they interrupted their regular programing and said there had ben an attempt against the president. They talked about how phones were not being picked up in his house and did not know exactly what was happening. Then channel went off the air. That's when I understood there had been a coup. " (Activist 5)

They also report clear repression against independent media, through electricity outages, signal shortages, equipment confiscation and the militarization of the national telecommunications company (Hondutel).

\footnotetext{
The largest communication media in Honduras, Radio America and HRN are Golpistas (organizer of the coup).... They influenced people's opinion in favor of the coup. But we also have new radio stations, such as Radio Globo and Radio Progreso and a large network of community radio throughout the country that don't agree with the coup, these radios did divulge what was really happening in the country. The reaction of authorities and the police was to immediately close these radio stations. All the equipment from Radio Globo and Radio Progreso were destroyed, the same way, Canal 36 was dismantled. However, they were able to broadcast news through the Internet (Activist 1).
}

This prompted them to actively seek for alternative means of information. During this phase they expresses having thirst for understanding what was happening and having an informed opinion on the matter. They would try to find information about the coup, in order to understand whether it was legal or not. They texted or emailed their contacts, friends and relatives, switched the radio dial to independent radio stations and went online to international news sites. It is at this stage where people change their media habits. 


\begin{abstract}
"During the next few hours we did not know how to proceed. There was no electricity, so we couldn't watch news on TV. My only source of information was my smart phone. It allowed me to be in touch with all my contacts. However I did not have an official version of what was happening. So I turned on the radio....large corporate radios had a version of the events and smaller radios another. Opinions were split" (International 2)
\end{abstract}

There was a hostile environment for those who rejected the coup, information was unavailable, media was being censored, thus people was forced to search for alternatives to be informed.

\title{
How the Movement Rose: Bricolage of Mobilizing Structures
}

Once they had informed themselves about what was happening, they resolved that next step was to show their outrage. People identified each other for the first time as being against the coup; they would spontaneously go to the streets and run into acquaintances and other people who had similar points of view. They would also recognize each other on listservs, Facebook or the newspapers. People who belonged to civil society organizations, ran into their colleagues and started using their already existing networks or "prior social ties" (D. McAdam, 2003) and resources to structure and organize the movement.

\footnotetext{
"Those of us who agreed that President Zelaya needed to be restituted, arbitrarily ran into each other in protests and meetings. We then started creating organizational structures. In time, we found out there was the need to get more organized and started planning our activities more carefully. Local and regional resistance fronts were formed." (Activist 5)
}

Thus the movement rose from individuals' initiative to protest, but was supported by the already existing organizational structures provided by the organizations people belonged to. The following is an excerpt from the movement' "founding statement".

\footnotetext{
"The FNRP is a tool for the construction of popular power, with full political and ideological independence from political parties, religious groups and other organizations or individuals. It is composed of popular movements, social organizations and policies that seek social transformation of the country. In it are represented residents and settlers, peasants, laborers and workers, micro small and medium enterprises and entrepreneurs, environmental movements, students, progressive NGOs, progressive and democratic political forces, teachers, professionals, human rights groups, youth, women, artists, people indigenous and black, lesbian, gay, bisexual and transgender (LGBT), popular churches, migrants and other organized and unorganized sectors." (FNRP)
} 


\section{Mobilizing Ideology}

Social movement studies have traditionally focused on studying mobilization of "people" who invest their time and labor to advance the cause of the movement (McAdam, et al., 1996); or the source and access to "resources" and its effect on the movement (Schwartz Ct Paul, 1992). In this case mobilization is regarded as diffusion; therefore the objects of mobilization are: ideas, practices, tactics and frames. This type of mobilization is the result of influence processes operating in multiple overlapping networks (Hedstrom et al, 2000; Gould, 1991); in other words the spread of practices from a group to another, movements get ideas about organization structure, action, tactics, strategies and ideological goals from other movements (McAdam and Rucht 1993). Throught he use of ICTs (e.g. Facebook groups, websites and blogs) the Honduran Resistance Movement was able to quickly spread information. Information was spread inwardly, to have debates and conversations and promote their cause. They used email distribution lists that were originally created for from organizations as places of discussion.

\footnotetext{
"There is a collective network called FIAT Internacional, you can subscribe to that network and you can have access to thousands of messages. FIAT has around 4000 people on line sending and receiving messages. My inbox gets full. You get information about the activities, events, and plans of the LGBT organizations, the women's organizations. On the Internet we send our statements to the FIAT network, and we also use our personal emails" (Activist 1)
}

They also spread information outwardly to raise awareness in the international community and put pressure on the de facto Honduran government (Della Porta \& Diani, 1999; Della Porta et al., 1999). Various members of the resistance and independent media who is part of the resistance movement explained how they approached the use of ICTs in a strategic way to get information out.

\footnotetext{
"We know that the world reads on line. Given the low technological lever in Honduras, we did not expect our website to have a great impact, but we did expect it to have international impact. Coup perpetrators did not realize for a long time that we were broadcasting information to the whole world through our website" (Media 2)
}

ICTs also made collaboration between movements more likely; reinforced the already existing social networks (Garret, 2006; Morris \& Mueller, 1992) and allowed the creation of weak ties between organizations within the movement (Granovetter,1973, 1983).

"The coup has awakened a lot of feelings amongst several organizations. We have worked feminist organizations such as CDM (Women's Rights Center). Before the coup these 
organizations would only work around women's rights issues, after the coup they have broadened their area of focus and have conducted studies on the attacks against women during and after the coup. The same thing has happened with lesbian-gay organizations, which had never participated in these kind of mobilization, and now thanks to communications and information they have gained conscience and are now participating actively against the coup with the resistance." (Activist 1)

ICTs provided a means for the rapid dissemination of information and organization through pre-existing circuits (Cleaver, 2000), this allowed the movement to organize, mobilize, diffuse information, strengthen ties and create new alliances and organizations, despite repression attempts and the fact that both the conservative sector and the military controlled most of the ICT infrastructure.

\begin{tabular}{|c|c|c|c|c|c|c|c|}
\hline ICT Type & $\begin{array}{l}\text { Convoke } \\
\text { people to } \\
\text { protests or } \\
\text { meetings. }\end{array}$ & $\begin{array}{c}\text { Inform } \\
\text { themselves } \\
\text { and others } \\
\text { about } \\
\text { objectives and } \\
\text { ideology }\end{array}$ & $\begin{array}{c}\text { Disseminate } \\
\text { info about } \\
\text { what was } \\
\text { "really } \\
\text { happening" }\end{array}$ & $\begin{array}{c}\text { Denounce } \\
\text { HR } \\
\text { Violations }\end{array}$ & $\begin{array}{l}\text { Have debates } \\
\text { and } \\
\text { conversations }\end{array}$ & $\begin{array}{l}\text { Campaigns } \\
\text { to educate } \\
\text { people }\end{array}$ & $\begin{array}{c}\text { To } \\
\text { Collaborate }\end{array}$ \\
\hline Facebook & & $\mathrm{X}$ & $\bar{X}$ & $\mathrm{X}$ & $\mathrm{X}$ & $\mathrm{X}$ & $\mathrm{X}$ \\
\hline \multicolumn{8}{|l|}{ Twitter } \\
\hline Blogs & $\mathrm{X}$ & $\mathrm{X}$ & $\mathrm{X}$ & $\mathrm{X}$ & & $\mathrm{X}$ & \\
\hline Websites & $\mathrm{X}$ & & & & & & $\mathrm{X}$ \\
\hline Youtube & & $\mathrm{X}$ & $\mathrm{X}$ & $\mathrm{X}$ & & $\mathrm{X}$ & \\
\hline Email: & $\mathrm{X}$ & $\mathrm{X}$ & $\mathrm{X}$ & $\mathrm{X}$ & $\mathrm{X}$ & $\mathrm{X}$ & $\mathrm{X}$ \\
\hline $\begin{array}{l}\text { Cellphone/Sma } \\
\text { rtphone }\end{array}$ & $\mathrm{X}$ & $\mathrm{X}$ & $\mathrm{X}$ & $\mathrm{X}$ & $\mathrm{X}$ & $\mathrm{X}$ & $\mathrm{X}$ \\
\hline Radio & $\mathrm{X}$ & $\mathrm{X}$ & $\mathrm{X}$ & $\mathrm{X}$ & $\mathrm{X}$ & $\mathrm{X}$ & $\mathrm{X}$ \\
\hline Television & $\mathrm{X}$ & $\mathrm{X}$ & $\mathrm{X}$ & $\mathrm{X}$ & $\mathrm{X}$ & $\mathrm{X}$ & \\
\hline Chat & & $\mathrm{X}$ & $\mathrm{X}$ & & $\mathrm{X}$ & & $\mathrm{X}$ \\
\hline SMS & $\mathrm{X}$ & $\mathrm{X}$ & $\mathrm{X}$ & $\mathrm{X}$ & $\mathrm{X}$ & $\mathrm{X}$ & $\mathrm{X}$ \\
\hline
\end{tabular}

Tahle 3. Purnose of Ise hv Tvne of ICT

Conclusion: Building Alternative Opportunity Structures

Social Movements are shaped by political constraints unique to the context in which they are embedded (Kitschelt, 1986; H. Kriesi, 2004; D. McAdam, 1982; Meyer, 2004; S. G. Tarrow et al., 1989; C. Tilly, 1979; C. Tilly, 1978). Furthermore, the political processes that pertain social movements are increasingly being played in the space of ICTs (M. Castells, 1999; M. Castells, 2000). The ability to create transnational computer-mediated networks has allowed the resistance movements to undercut the national government, allowing them to play a larger role on the international scene. The movement evolved from using ICTs tools for mobilization into a "kind of electronic fabric of opposition to much wider policies" (Cleaver, 2011). They focused their efforts toward improvising alternative "political forms that reconciled technical competence and participatory democracy" (HAGER, 1993\}). The fist instance is the way they got the attention and support of the 
international community. They used networks of independent journalists like Witness for Peace and human rights organizations like Amnesty International to put pressure for the Organization of American States (OAS) in order to sanction Honduras for being a dictatorship. The second instance is the creation of a political party. In Honduras, political rather than social capital links formal group activism to democracy in (BOOTH \& RICHARD, 1998; Bootha \& Richarda, 1999), thus the resistance movement formed a political party and participated in the 2012 primary elections.

\section{REFERENCES}

Alinsky, S. D. (1941). Community analysis and organization. The American Journal of Sociology, 46(6), 797-808.

Ameripour, A., Nicholson, B., \& Newman, M. (2010). Conviviality of internet social networks: An exploratory study of internet campaigns in iran. Journal of Information Technology, 25(2), 244-257.

Babbie, E. R. (2008). The basics of social research Wadsworth Pub Co.

Boggs, C. (1983). The intellectuals and social-movements - some reflections on academic marxism. Humanities in Society, 6(2-3), 223-239.

BOOTH, J. A., \& RICHARD, P. B. (1998). Civil society and political context in central america. American Behavioral Scientist, 42(1), 33-46.

Bootha, J. A., \&t Richarda, P. B. (1999). Civil society, political capital, and democratization in central america. The Journal of Politics, 60, 780-800.

Buechler, S. M. (1995). New social movement theories. Sociological Quarterly, 36(3), 441-464.

Buechler, S. M. (2000). Social movements in advanced capitalism: The political economy and cultural construction of social activism. New York: Oxford University Press.

Burawoy, M. (1991). Ethnography unbound :Power and resistance in the modern metropolis. Berkeley: University of California Press.

Burawoy, M. (1998). The extended case method. Sociological Theory, 16(1), 4-33.

Carty, V. (2011). Wired and mobilizing: Social movements, new technology, and electoral politics Taylor \& Francis.

Carty, V. (2010). New information communication technologies and grassroots mobilization. Information Communication \& Society, 13(2), 155-173.

Castells, M. (2000). The rise of the network society. Cambridge, Mass.: Blackwell Pub.

Chong, D. (2000). Rational lives :Norms and values in politics and society. Chicago, III.: University of Chicago Press.

Ciborra, C. U. (1992). From thinking to tinkering: The grassroots of strategic information systems. The Information Society, 8(4), 297-309.

Davis, F. D., \& Zald, M. N. (2005). Social change, social theory and convergence of movements and organizations. Social movements and organization theory (pp. 4). 
Cambridge; New York: Cambridge University Press.

Della Porta, D., Kriesi, H., \& Rucht, D. (1999). Social movements in a globalizing world. New York: St. Martin's Press.

Donk, W. B. H. J. v. d. (2004). Cyberprotest : New media, citizens, and social movements. London; New York: Routledge.

Eltantawy, N., \& Wiest, J. B. (2011). Social media in the egyptian revolution: Reconsidering resource mobilization theory. International Journal of Communication, 5, 1207-1224.

Feagin, J. R., Sjoberg, G., Sjoberg, G., Williams, N., Vaughan, T. R., Sjoberg, A. F., et al. (1991). A case for the case study.

Frank, D. (Jan 31, 2011, Jan 31, 2011). US: Wrong on honduras. The Nation, $292,7$.

Garrett, R. K. (2006). Protest in an information society: A review of literature on social movements and new ICTs. Information, Communication \& Society, 9(2), 202-224.

Granovetter, M. (1983). The strength of weak ties: A network theory revisited. Sociological Theory, 1, pp. 201-233.

HAGER, C. (1993\}). Citizen movements and technological policy-making in germany. Annals of the American Academy of Political and Social Science\}, 528\}, 42-55\}.

Hatton, E. (1989). Lévi-strauss's bricolage and theorizing teachers' work. Anthropology \& Education Quarterly, 20(2), 74-96.

Hess, D., Breyman, S., Campbell, N., \& Martin, B. (2008). Science, technology, and social movements. The Handbook of Science and Technology Studies, , 473-498.

Hess, D. (2005). Technology- and product-oriented movements: Approximating social movement studies and science and technology studies. Science Technology \& Human Values, 30(4), 515-535.

Kitschelt, H. (1986). Political opportunity structures and political protest: Anti-nuclear movements in four democracies. British Journal of Political Science, 16(1), 57-85.

Klein, J. (2012). Wikileaks, arab uprisings, english riots and occupy wall street: Implications for internet policy and practice from a business and industry outcome perspective. Information, Communication \& Society Journal, (14.6)

Kriesi, H. (1995a). The political opportunity structure of new social movements: Its impact on their mobilization. The politics of social protest: Comparative perspectives on states and ... (J. Craig Jenkins, Bert Klandermans ed., pp. 167-198) Minneapolis: University of Minnesota Press.

Le Dantec, C. A. (2012). Considering the rights (and wrongs) of community technology. Interactions, 19(4), 24-27.

Lebert, J. (2003). Wiring human rights activism: Amnesty international and the challenges of information and communication technologies. Cyberactivism: Online activism in theory and practice (). London and New York: Routledge.

Lichterman, P. (2002). Seeing structure happen: Theory-driven participant observation. Methods of social movement research (pp. 118) Univ of Minnesota Pr.

Marx, K., Engels, F., \& Smelser, N. J. (1973). On society and social change. Chicago: Uni- 
versity of Chicago Press.

McAdam, D. (2003). Beyond structural analysis: Toward a more dynamic understanding of social movements.

Social movements and networks: relational approaches to collective action (pp. 281-298) Oxford: Oxford University Press.

McAdam, D., Tarrow, S. G., \&t Tilly, C. (2001). Dynamics of contention. New York: Cambridge University Press.

Melucci, A., Keane, J., \&t Mier, P. (1989). Nomads of the present : Social movements and individual needs in contemporary society / alberto melucci ; edited by john keane and paul mier Hutchinson Radius, London.

Meyer, D. S. (2004). Protest and political opportunities. Annual Review of Sociology, 30, pp. 125-145.

Moghadam, V. M. (2012). Globalization and social movements: Islamism, feminism, and the global justice movement Rowman \& Littlefield Publishers.

Njenga, K., \& Brown, I. (2012). Conceptualising improvisation in information systems security. European Journal of Information Systems, 21(6), 592-607.

Olson, M. (1971). The logic of collective action;public goods and the theory of groups. Cambridge, Mass.: Harvard University Press.

Park, R. E. (1939). Collective behavior. American Sociological Review, 4(3), 404-406.

Peetz, P. (2009). Honduras: A coup that nobody wanted. GIGA Focus Lateinamerika, (7), 1-8.

Pichardo, N. A. (1997). New social movements: A critical review. Annual Review of Sociology, 23(1), 411-430.

Ruhl, J. M. (2010). Honduras unravels. Journal of Democracy, 21(2), 93-107.

Silva, L. 0. (2002). Outsourcing as an improvisation: A case study in latin america. Information Society, 18(2), 129-138.

Singerman, D. (2004). The networked world of islamist social movements. Op.Cit, , 143-163.

Smelser, N. J. (1963). Theory of collective behavior. New York: Free Press of Glencoe.

Snow, D. A., Rochford, E. B., Worden, S. K., \& Benford, R. D. (1986). Frame alignment processes, micromobilization, and movement participation. American Sociological Review, 51(4), 464-481.

Snow, D. A., \&t Trom, D. (2002). Methods of social movement research. In B. Klandermans, \& S. Staggenborg (Eds.),

Methods of social movement research (pp. 146) Univ of Minnesota Pr.

Tarrow, S. G. (2011). Power in movement: Social movements and contentious politics Cambridge University Press.

Tilly, C. (2002). Stories, identities, and political change. Lanham, Md.: Rowman \& Littlefield.

Warren, M. R. (2001). Dry bones rattling :Community building to revitalize american democracy. Princeton, N.J.: Princeton University Press. 